\title{
ナフテン酸鉛の熱分解による $\mathrm{PbO}$ 薄膜の生成過程
}

\author{
福島 純・小平紘平・綱島 群・松下 徹 \\ (北海道大学 工学部 応用化学科)
}

\section{Formation Process of $\mathbf{P b O}$ Thin Film by Thermal Decomposition of Lead Naphthenate}

\author{
By \\ Jun FUKUSHIMA, Kohei KODAIRRA, Atsumu TSUNASHIMA and Toru MATSUSHITA \\ (Department of Applied Chemistry, Faculty of Engineering, Hokkaido University)
}

\begin{abstract}
Polycrystalline and transparent $\mathrm{PbO}$ thin films showing interference color were obtained from the $10 \mathrm{wt} \%$ butanol solution of lead naphthenate applied on soda lime glass (slide glass) and fused silica substrates by heating above $550^{\circ} \mathrm{C}$ for 30 minutes. The process of the film formation was examained by $\mathrm{X}$-ray diffraction, electron diffraction and IR spectra.

After vaporizing of butanol at $110^{\circ} \mathrm{C}$, lead naphthenate films were formed by heating below $200^{\circ} \mathrm{C}$ and $\mathrm{PbO}$ powders with the particle size of about $1 \mu$ were formed homogeneously on the substrate by the thermal decomposition of lead naphthenate film at the temperature range of 300 to $500^{\circ} \mathrm{C}$. The lead naphthenate films were completely decomposed at $400^{\circ} \mathrm{C}$ to form a substance layer with low melting point for soda lime glass and to form lead silicate layer for fused silica at about $500^{\circ} \mathrm{C}$. As the result, $\mathrm{PbO}$ powders were interconnected to form transparent and uniform films on there reaction products layer. The film thickness was decreased with proceeding of the reaction between $\mathrm{PbO}$ powders and the substrate. The film bonded firmly with the substrate as the heating temperature rises.

It may be concluded that the reaction between the $\mathrm{PbO}$ powders and the substrates was concerned in the formation of transparent and uniform $\mathrm{PbO}$ thin film.
\end{abstract}

[Received August 9, 1974]

\section{1. 緒言}

金属酸化物の薄膜はエレクトロニクス, 光学などへ広 く応用されている. 一般に酸化物薄膜をガラス基板上に コーティングする方法には酸化物の真空蒸着, 金属蒸着 膜の酸化, 化学蒸着法 ${ }^{1)}$, 塗布法 ${ }^{2)}$, などがある.このう ち塗布法は, 金属化合物の溶液を基板にコーティングし た後焼成して酸化物薄膜を生成する方法であり, 特にそ の手順の容易さおよび基板の任意の場所への生成が可能 であることなどの特徴を持つが, 均一な薄膜が得られる 原料の選択が難しく, 塗布法によって生成された酸化物 薄膜に関する報告は少ない(3),4). 著者らは以前に原料と してカプリル酸錫のブタノール溶液を用いることによ って透明な導電性酸 化錫薄膜を生成することができ $た^{5)}$. この場合, カプリル酸錫からの透明な $\mathrm{SnO}_{2}$ 膜の 生成過程として, $110^{\circ} \mathrm{C}$ の乾燥でカプリル酸錫が加水分 解して非晶質 $\mathrm{SnO}$ 膜が生成し, その後の焼成によって 有機物の分解と $\mathrm{SnO}$ の酸化および $\mathrm{SnO}_{2}$ の結晶化が進 行するという過程を推察した.
本研究では, ナフテン酸鉛のブタノール溶液をガラス 基板上に塗布して後, 焼成することにより透明な $\mathrm{PbO}$ の薄膜が生成でき，その生成過程は上記 $\mathrm{SnO}_{2}$ 薄膜の 場合と著しく異なっていたので, それらの詳細について 検討した結果を報告する.

\section{2. 実 験 方 法}

原料は，播磨化成工業（株）製溶液状ノーデックス鉛 (ナフテン酸鉛 $\mathrm{Pb}: 26 \mathrm{wt} \%$ ) を用い，これを特級 $n$ ブタノールに溶玑して 0.5 20 wt \% 溶液を調製し試料 溶液とした。

基板には，市販のスライドガラスと透明石英板を使用 した. 基板表面は，中性洗剤で充分洗涤し，30 wt \% 過 酸化水素中に数週間浸漬した後そのまま超音波洗涤を行 った ${ }^{6}$. この基板上に上記試料溶液をスポイトで滴下 し, 均一に拡がった後, 基板を傾斜させて余分の試料を 除去した.これを水平に保って大気中で 1 時間自然乾燥 を行い, さらに $110^{\circ} \mathrm{C}$ で 1 時間乾燥を行った. その後, 
$200 \sim 800^{\circ} \mathrm{C}$ の各所定温度に保った横型電気炉中に挿入 し, 30 分から 3 時間焼成を行って薄膜を生成させた.

焼成による有機物の分解過程は, IR スペクトル（日 立製 EPI-2 型）によって調べた. また基板上の生成物 は, 削り取って透過電子線回折および粉末 $\mathrm{X}$ 線回折を 行い, 特に高温 $\left(550 \sim 800^{\circ} \mathrm{C}\right)$ で焼成した試料について は, そのほかに基板上に生成した薄膜のままでX線回折 を行った. 電子線回折には日立製電子顕微鏡 HS-7 型 を，X線回折には東芝 GD-3 H 型を用いた。

各焼成温度で生成した薄膜の表面状態は 2 段レプリカ 法により電子顕微鏡で観察した. また $600^{\circ} \mathrm{C}$ 以上で焼 成した膜については, そのほかに $2 \mathrm{~N}-\mathrm{HCl}$ 溶液で 20 秒間エッチングし，その表面状態を調べた.

膜厚の測定には次の方法を用いた. $110^{\circ} \mathrm{C}$ の乾燥でほ ぼ固化した叙布膜を削り取って部分的に基板面を露出さ せて焼成し, 膜面と基板上との高さの差を繰り返し反射 干涉計（オリンパス製 MBI 型）によって測定した7).

\section{3. 結果および考察}

\section{1 薄膜の生成状態および生成物}

予備実験において, 各濃度の試料からの薄膜の生成状 態を調べたところ, 濃度 $3 \sim 10 \mathrm{wt} \%$ の溶液を用いた場 合に $\mathrm{PbO}$ 薄膜が得られたが, 焼成温度が低い場合には 粉末状 $\mathrm{PbO}$ が生成するといら結果が得られた. そこで 最も濃度の高い $10 \mathrm{wt} \%$ 組成を中心に実験を行った. この組成を用い 30 分焼成した場合の焼成温度に対する 薄膜の生成状態, 生成相および膜厚をまとめて 表-1に 示した.

濃度 $10 \mathrm{wt} \%$ 試料溶液の場合に，基板としてスライ ドガラスを用いると, $110^{\circ} \mathrm{C}$ の乾燥で半透明の固化した 膜となり，これについて IR 吸収分析を行うと原料であ るノーデックス鉛の吸収スペクトルと一致し， $n$-ブタノ 一ルによる吸収ピークは認められなかった. $200^{\circ} \mathrm{C}$ の焼 成では膜に大きな変化は無かったが， $300 \sim 400^{\circ} \mathrm{C}$ で焼 成した場合には, 固化膜は熱分解して黄色粉末が基板上

Table 1. Products obtained from lead naphthenate (10 wt $\%$ butanol solution) by heating at $300 \sim 800^{\circ} \mathrm{C}$ for 30 minuites.

\begin{tabular}{|c|c|c|c|c|}
\hline $\begin{array}{l}\text { Subst } \\
\text { Temp. }\end{array}$ & $\left({ }^{\circ} \mathrm{C}\right)$ & Products & $\underset{\substack{\text { Film } \\
\text { thickness } \\
(\AA)}}{\text { (A) }}$ & Remarks \\
\hline \multirow{5}{*}{$\begin{array}{l}\text { Soda- } \\
\text { lime } \\
\text { glass }\end{array}$} & 300 & $\mathrm{PbO}$ (Tetra.) & - & yellow powders \\
\hline & 400 & PbO(Tetra.) & - & yellow powders \\
\hline & 500 & $\begin{array}{l}\text { PbO(Tetra.), } \\
\text { PbO(Ortho.) }\end{array}$ & 1300 & $\begin{array}{l}\text { yellow powders (partially } \\
\text { transparent film) }\end{array}$ \\
\hline & 550 & $\begin{array}{l}\text { PbO(Ortho.), } \\
\text { PbO(Tetra.) }\end{array}$ & 900 & transparent film \\
\hline & 600 & $\begin{array}{l}\text { PbO(Ortho.), } \\
\text { lead silicate }\end{array}$ & 400 & transparent film \\
\hline \multirow{3}{*}{$\begin{array}{l}\text { Fused } \\
\text { silica }\end{array}$} & 600 & PbO(Ortho.) & 400 & transparent film \\
\hline & 700 & $\begin{array}{l}\mathrm{PbO}(\text { Ortho.), } \\
\mathrm{PbSiO}_{8}\end{array}$ & - & transparent film \\
\hline & 800 & $\begin{array}{l}\mathrm{PbO}(\text { Ortho.) } \\
\mathrm{PbSiO}_{3}\end{array}$ & - & transparent film \\
\hline
\end{tabular}

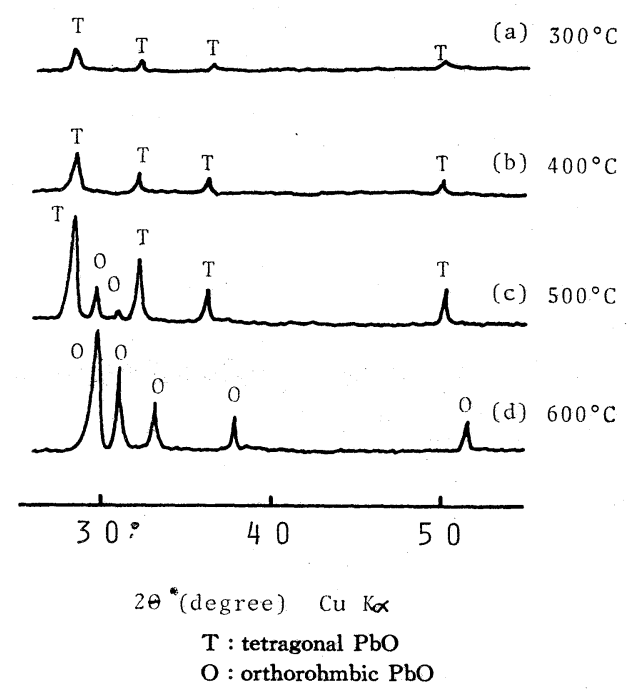

Fig. 1. X-ray diffraction patterns of the products.

に生成した.これを削り取って $\mathrm{X}$ 線回折すると図-1(a), (b) のよ5に $\mathrm{PbO}$ (正方晶) であり, $400^{\circ} \mathrm{C}$ 焼成の場 合の回折線の方がやや鋭くなっていた. また，IR 吸収 スペクトルを測定すると, $300^{\circ} \mathrm{C}$ から有機物による吸収 ピークが急速に減少し始め, $400^{\circ} \mathrm{C}$ でほぼ消失した. し たがって, 約 $300^{\circ} \mathrm{C}$ から有機物の 熱分解にともなって $\mathrm{PbO}$ が生成し始め, $400^{\circ} \mathrm{C}$ では $\mathrm{PbO}$ のみが基板上に 存在しているものと考えられる.

$500^{\circ} \mathrm{C}$ 焼成の場合には, 基板上生成物は一部透明化し た. X線回折を行うと, 図-1(c) のように $\mathrm{PbO}$ (正方 晶) のほかに微弱な $\mathrm{PbO}$ (斜方晶) の回折線も認めら れた. $550^{\circ} \mathrm{C}$ 焼成の場合には均一でかつ強く基板に固着 した透明な薄膜が得られ, 薄膜を削り取ってX線回折し た結果, $\mathrm{PbO}$ (斜方晶) の回折強度は増加し, 正方晶の 回折強度は減少していた. なお, 同温度で 30 分以上焼 成すると, $\mathrm{PbO}$ (斜方晶) の回折強度はさらに増加し た.

$600^{\circ} \mathrm{C}$ 焼成によって生成した透明な薄膜は非常に強固 であった.これを削り取ってX線回折すると，図-1 (d) のように $\mathrm{PbO}$ (斜方晶) の回折線のみが得られた. し かし, 基板上に生成したままで薄膜の X 線回折を行う と, $\mathrm{PbO}$ (斜方晶) は検出されず, $550^{\circ} \mathrm{C}$ 以下の場合で は得られなかった未知の複雑な回折図形が得られた.こ の未知物質については同定は困難であったが，おそらく $\mathrm{PbO}$ とスライドガラスとの反応生成物であろうと思わ れる。したがって,この場合基板上には上層にX線では 検出できないほど薄い $\mathrm{PbO}$ (斜方晶) の膜があり, そ の下にスライドガラス基板と $\mathrm{PbO}$ との反応生物から成 なる層が存在しているものと考えられる.

さらに, 膜の透明化がおこる温度を確認するために, 400,450 および $500^{\circ} \mathrm{C}$ において長時間（ 3 時間以上） 
燒成した場合の膜の生成状態を調べてみると， $400^{\circ} \mathrm{C} お$ よび $450^{\circ} \mathrm{C}$ の場合には $\mathrm{PbO}$ は粉末のままであり, $500^{\circ} \mathrm{C}$ の場合は 30 分焼成物に比べて透明部分がやや増 加するといら結果が得られた。

石英板を基板に用いた場合には表-1に示したように， 薄膜が透明となる温度が高く $\left(600^{\circ} \mathrm{C}\right.$ 以上)，ます $700^{\circ} \mathrm{C}$ および $800^{\circ} \mathrm{C}$ 焼成で得られた膜につき基板のまま $\mathrm{X}$ 線 回折した場合に $\mathrm{PbSiO}_{3}$ が検出されたほかはスライドガ ラス基板を用いた場合とほとんど同様であった。

次に，スライドガラスを基板とし濃度 0.5 1 wt \% 試料を用いると，粉末状龍を経過せずに $400^{\circ} \mathrm{C}$ で直接 透明な薄膜となった。生成膜は数百 $\AA$ の厚さであり， 削り取ることができなかったので生成相の同定はできな かった.濃度 $20 \mathrm{wt} \%$ 試料の場合は, $600^{\circ} \mathrm{C} て ゙ 30$ 分か ら 3 時閒焼成しても透明な薄膜とならず粉末状の $\mathrm{PbO}$ (斜方晶) が生成したほかは，上記 $10 \mathrm{wt} \%$ 試料の場合 と同様であった。

膜厚は 表-1 に示すよ5に，30 分焼成の場合は焼成温 度の上暴と共に減少し，また別に同一温度で烧成時閐を 増加しても膜厚は減少した。これらを図示すると図-2 (膜厚一焼成温度) および. 図-3 (膜厚一焼成時閒) のよ らになった。

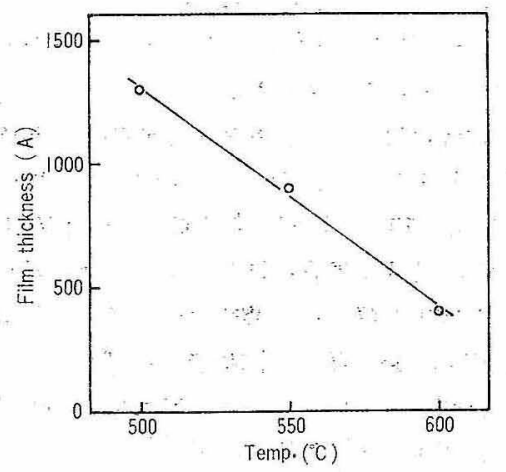

Fig. 2. Thickness of the films for calcining at $500,-550$ and $600^{\circ} \mathrm{C}$ for $30 \mathrm{~min}$.

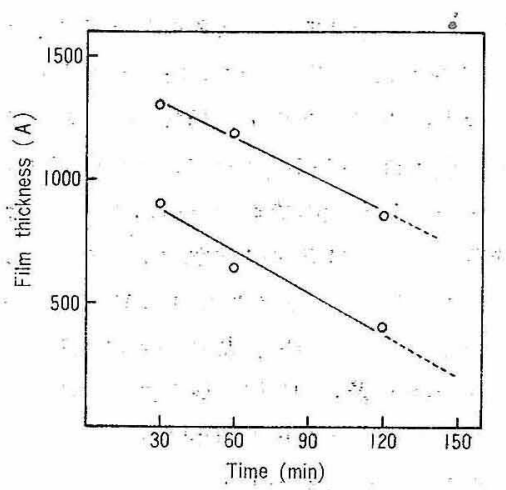

Fig. 3. Thickness of the films for the change in calcining durations at 500 and $550^{\circ} \mathrm{C}$.

\section{2 表面状態の電子䫘微鏡観察}

濃度 10 wt\% 試料を用いて, 400,500 および $600^{\circ} \mathrm{C}$ 30 分焼成した膜のレプリカ写真を図-4に示した. $400^{\circ} \mathrm{C}$ 焼成 (図-4 (a)) では, 径約 $1 \mu$ の $\mathrm{PbO}$ 粒子 が互いに隣接して比較的均一に分布しているが, $500^{\circ} \mathrm{C}$ 焼成の場合 (図-4 (b)) には粒子柱密着し合い， $600^{\circ} \mathrm{C}$ で焼成すると（図-4(c)）表面はほぼ平滑になった。ま た, $600^{\circ} \mathrm{C}$ で長時閒焼成 (1 3 時閒)すると, 表面に嚾 かに四凸が現われる傾向があった。

$600^{\circ} \mathrm{C}-30$ 分焼成膜 (図-4 (c)) 学 $2 \mathrm{~N}-\mathrm{HCl}$ 溶澕 20 秒間腐蝕すると, 図-5に示すように非常に凹凸の激し 认表面状態となった. 石英ガラス基板を用いて同じ条件

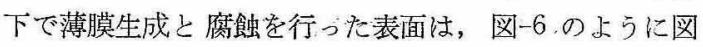
-3 とは異なった回かが観察された。このような應蝕後 の表面状態の差は， $\mathrm{PbO}$ 層の下に存在寸る反応生成物 層の違いによるものであると考えられる。

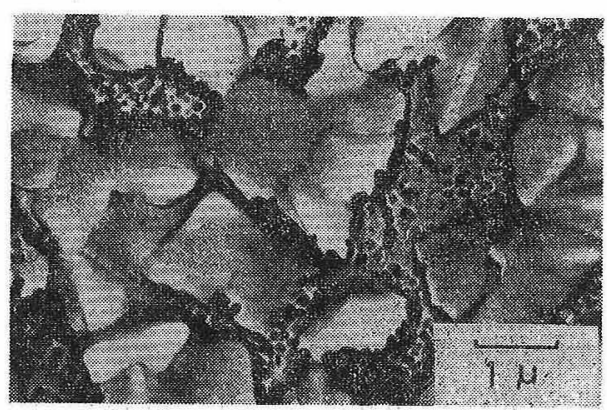

(a) $400^{\circ} \mathrm{C}$

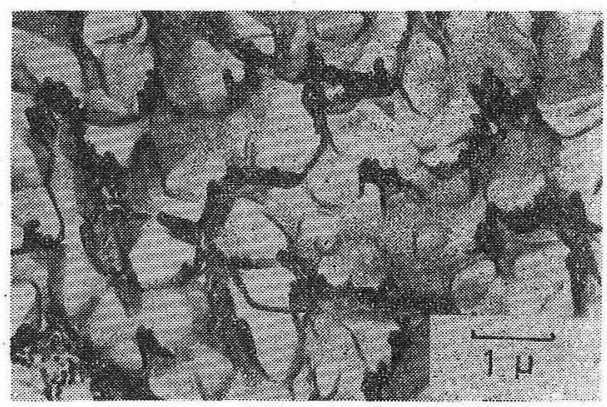

(b) $500^{\circ} \mathrm{C}$

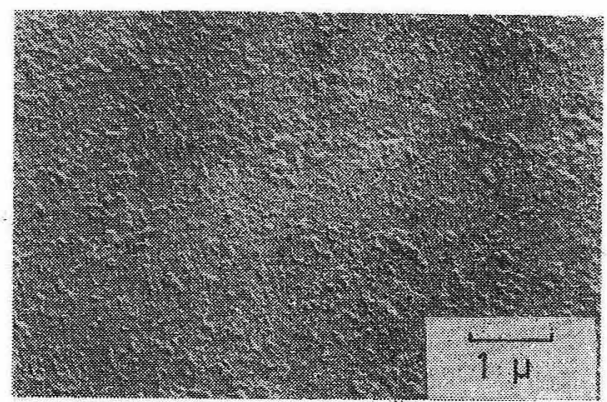

(c) $600^{\circ} \mathrm{C}$

Fig. 4. Electron micrographs of the products on the slide glass substrate. 


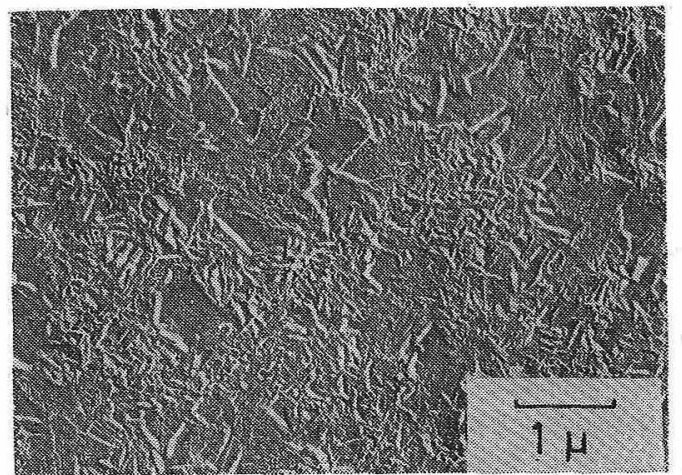

Fig. 5. Electron micrograph of the film formed on the slide glass at $600^{\circ} \mathrm{C}$ from $10 \mathrm{wt} \%$ butanol solution. (after etched by $2 \mathrm{~N}-\mathrm{HCl}$ )

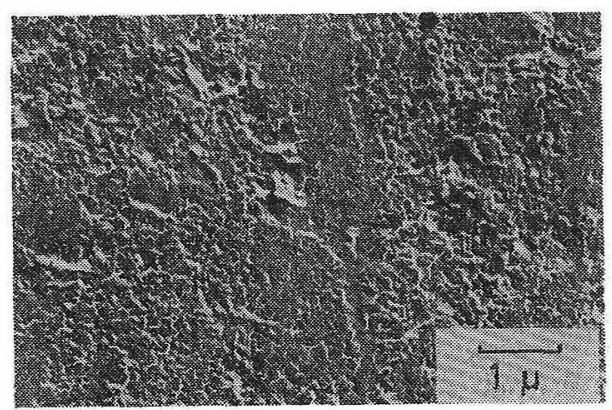

Fig. 6. Electron micrograph of the film formed on the fused silica at $600^{\circ} \mathrm{C}$ from $10 \mathrm{wt} \%$ butanol solution. (after etched by $2 \mathrm{~N}-\mathrm{HCl}$ )

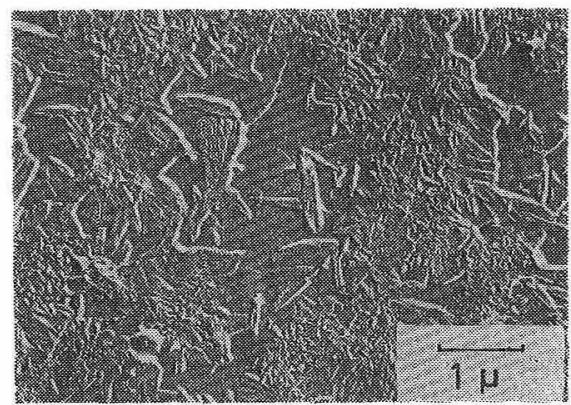

Fig. 7. Electron micrograph of the film formed on the slide glass at $600^{\circ} \mathrm{C}$ from $0.5 \mathrm{wt} \%$ butanol solution.

漫度 $0.5 \mathrm{wt} \%$ 試料莸用い $600^{\circ} \mathrm{C} 30$ 分㜔成した膜の 表面は，図-7 に示すように図-5 と良く一致した表面状 態な示した.

\section{$3.3 \mathrm{PbO}$ 薄膜の生成過程}

3.1 および 3.2 の結果を総合し, $\mathrm{PbO}$ 薄暮の生成過 程を図式化すると図-8のようになる.すなわら, 濃度 $10 \mathrm{wt} \%$ 溶液を用いた場合， $110^{\circ} \mathrm{C}$ 乾燥および $200^{\circ} \mathrm{C}$ 莊 成では原料のノーデックス鉛务らなる固化膜が生成し， $300^{\circ} \mathrm{C}$ 加ら正方晶 $\mathrm{PbO}$ が生成し始める。 $400^{\circ} \mathrm{C}$ 焼成で 有機物が完全に分解し去り, 約 $500^{\circ} \mathrm{C}$ から正方晶 $\mathrm{PbO}$

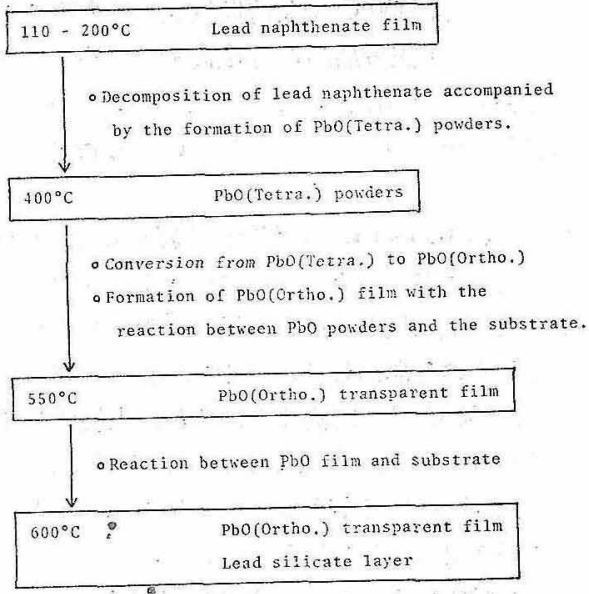

Fig. 8. Process of formation of $\mathrm{PbO}$ thin film for the slide glass substrate.

は斜方晶へと変化し始め， $600^{\circ} \mathrm{C}$ でほぼ斜方晶のみとな った．基板としてスライドガラスる朋いた場合は，300 $\sim 400^{\circ} \mathrm{C}$ で一旦粉末化した膜は，500 $\mathrm{C}$ の焼成で一部透

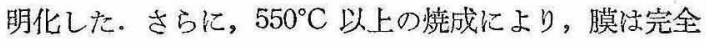
に透明化し， $600^{\circ} \mathrm{C}$ では $\mathrm{PbO}$ 斜方晶の透明な膜の下 に，末知の反応生成物層が認めら机た。これに対して, 石英ガラス基板の場合には，透明な $\mathrm{PbO}$ 薄膜は $600^{\circ} \mathrm{C}$ 以上の焼成で生成し, $700^{\circ} \mathrm{C}$ 以上の加熱で $\mathrm{PbO}$ 膜の下 に $\mathrm{PbSiO}_{3}$ の結晶化が認められた。すなわち，いずれの 基板を使用した場合にも約 $300^{\circ} \mathrm{C}$ で $\mathrm{PbO}$ 粒子と基板 との間に反忘が起こり（スライドガラス：約 $500^{\circ} \mathrm{C}$, 石英板 : 約 $600^{\circ} \mathrm{C}$ ), 膜の透明化が進えだものと考えられ る. スライドガラス基板の場合には, $\mathrm{PbO}-\mathrm{Na}_{2} \mathrm{O}-\mathrm{CaO}$ $\mathrm{SiO}_{2}$ 系からなる反応生成物が考えられるが, これに近 い組成の $\mathrm{PbO}-\mathrm{Na}_{2} \mathrm{O}-\mathrm{SiO}_{2}$ 策ガラスの軟化温度（粘度： $5 \times 10^{7}$ poise) は $440 \sim 480^{\circ} \mathrm{C}$ であり ${ }^{8}$ ，この洫度は本実 験において透明化の始まる $500^{\circ} \mathrm{C}$ に近い，石英ガラス 基板の場合には， $\mathrm{PbO}-\mathrm{SiO}_{2}$ 系からなる反应生成物が考 えられ，奏際 $\mathrm{PbSiO}_{3}$ が結晶化したが，この系のガラス の軟化温度は $520 \sim 580^{\circ} \mathrm{C}$ であり ${ }^{8)}$ ，この温度は同しくく 透明化する $600^{\circ} \mathrm{C}$ に近い.

以上のことから， $\mathrm{PbO}$ の透明な薄膜は，300 400 $\mathrm{C}$ で均一に生成した $\mathrm{PbO}$ 粒子の一部が基板と反心, 前 述の低融点物質が生成し, それにとむなって図-3 (b), (c) のよ5に，粹子の密着が起こり透明な薄膜となった ものと考えられる。したがって，この薄膜では基板表面 に低融点反忘生成物層が存在し，冬の上に透明化した $\mathrm{PbO}$ 層が存在している。

前述のように，焼成温度が高いほど，灾た同じ温度で も焼成時閒が長いほど膜厚は隇少していることから，焼 成時間の増加および温度の上昇と共に $\mathrm{PbO}$ 膜と基板と の反応はさらに基板内部に向って進行していくものと推 
察される.また， $450^{\circ} \mathrm{C}$ で長時間焼成しても膜の透明化 が起らず，PbO 正方晶から斜方晶への転移の始まる約 $500^{\circ} \mathrm{C}$ で初めて透明化が起こることから， $\mathrm{PbO}$ の結晶 系の転移が基板との反応に寄与している可能性が考えら れる。

濃度が低い $0.5 \sim 1 \mathrm{wt} \%$ 溶液の場合には, $400^{\circ} \mathrm{C}$ 焼 成で透明化したが，この場合には生成する $\mathrm{PbO}$ 層が非 常に薄いために基板との反応が低温においてでも短時間 で終了したものと思われる.これに対して $20 \mathrm{wt} \%$ の 場合には， $600^{\circ} \mathrm{C}$ で 3 時間またはそれ以上焼成しても透 明な薄膜が得られなかったことから，生成した多量の $\mathrm{PbO}$ 粒子が基板と充分反応するためには, 相当の高温 と長時間が必要であるものと思われる。

カプリル酸錫からの透明な $\mathrm{SnO}_{2}$ 膜の生成について は, カプリル酸錫の低温における加水分解で非晶質の $\mathrm{SnO}$ 膜が生成し, その後の焼成により $\mathrm{SnO}_{2}$ 膜となる といら過程を推察した5). しかし, 本実験においては, これとは異なり, 基板との反応が大きく関与した過程に よって透明な $\mathrm{PbO}$ 薄膜が生成することが明らかとなっ た.

\section{4. 総 括}

ノーデックス鉛のブタノール溶液をスライドガラスあ るいは透明石英板上に塗布した後，乾燥焼成することに
よって, 透明な $\mathrm{PbO}$ 薄膜が得られたので, その生成過 程について考察した結果を以下にまとめる.

1) 透明な $\mathrm{PbO}$ 薄膜は, $300 \sim 400^{\circ} \mathrm{C}$ で生成した $\mathrm{PbO}$ 粒子と基板とが反応し低融点物質を生成することによ。 て形成される．したがって，生成膜は $\mathrm{PbO}$ 層および反 応生成物層の二層から成っている.

2）膜厚は，焼成の温度および時閵の増加にともない 減少する.

3）試料濃度が高い場合には, 多量の $\mathrm{PbO}$ 粒子が生 成するので，より高温時間の焼成が必要であるが，粒子 の分布にむらがあるので良好な薄膜の生成は期待できな い.

4) 最も均一でかっ厚い $\mathrm{PbO}$ 薄膜を生成するのは, $10 \mathrm{wt} \%$ 試料を用いた場合である.

\section{文献}

1）武藤隆二郎, 古内重正, 応用物理 41 [2] 134 (1972).

2) 石川朝邦, 悹協 66, C 250 (1958).

3) R.J. Rockhart, J. Magder, J. Am. Ceram. Soc. 41, 299 (1966).

4) P.D. Payne, U.S.P. 3005731 (Oct. 24 1961).

5）松下 徹, 山井 嶡, 関谷 忠, 日化 77, 5 (1972).

6）砂山誠治, 超音波加工研究会資料 1, 5 (1960).

7) S.J. Lins, Am. Vacuum Soc. 2, 846 (1961).

8）松下 徹, 北大工研究報告 71, 145 (1974).

(8/9/1974 受付) 